\title{
Making rain, making roads, making do: public and private adaptations to drought in Ceará, Northeast Brazil
}

\author{
Timothy J. Finan*, Donald R. Nelson \\ Bureau of Applied Research in Anthropology (BARA), University of Arizona, Anthropology Building Room 316, \\ PO Box 210030, Tucson, Arizona 85721-0030, USA
}

\begin{abstract}
The Northeast of Brazil is characterized by a semi-arid environment with highly variable rainfall and frequent drought. Its population, particularly rural inhabitants who practice rainfed agriculture, are especially vulnerable to climatic extremes that compromise fragile livelihood systems. Since the end of the 19th century, the government has assumed the responsibility for solving the drought problem through programs designed to reduce immediate impacts and permanently diminish the overall vulnerability of the population. This paper focuses on the central northeastern state of Ceará, where the history of drought has been particularly savage and the public policy response particularly ambitious. Based on 3 yr of research, it first documents the vulnerability of rural Ceará, then traces the history of public efforts to mitigate these climatic crises, with particular focus on the role of seasonal forecasting. At the same time, the paper uses field data to report household coping mechanisms of rural inhabitants to drought. The conclusions argue for the need to combine both public and private responses in effective drought planning.
\end{abstract}

KEY WORDS: Drought $\cdot$ Vulnerability $\cdot$ Seasonal forecasting

Resale or republication not permitted without written consent of the publisher

\section{INTRODUCTION}

The nature, indeed the definition, of drought is highly scale-sensitive. At a regional level, where climate science feels most comfortable, drought is defined in terms of precipitation and evapotranspiration, measures that objectify the phenomenon as purely climatic, thus excluding any human dimension. At a local level, however, rainfall is only part of the drought equation, since 2 households subjected to the same rainfall regime may suffer radically different, even opposite, impacts. At this level, then, drought is as much a socio-economic phenomenon as a climatic one. To understand the variability in climatic impacts on local populations, social science has employed the concept of vulnerability (Liverman 1990, Davies 1996, p. 27, Ribot et al. 1996), building upon the earlier contributions of Watts (1983), Corbett (1988), and others. Vulnerability is, of course, a negative condition in the

*E-mail: finan@u.arizona.edu sense that its absence becomes a desired social goal. But in the dynamics of drought response, vulnerability serves as an important heuristic concept for assessing both the sensitivity to climatic extremes, i.e. the destructive consequences, and the resilience of households, i.e. the capacity to recuperate from disaster.

At a finer scale of analysis, anthropological household studies (e.g. Finan 1994, Baro 1997) have sought to identify and quantify the factors that would permit a classification of households based on relative levels of household vulnerability. This body of research has also depicted the strategies that different households employ to cope with climate-based transitional crises. At a regional analytical level, research has tended to focus on public policy and its role in drought alleviation (e.g. Wilhite \& Easterling 1987, Magalhães 1993) or as de Carvalho (1994) has put it, to discover how society can 'live with drought'. In reality, the process of adaptation to extreme climate variability entwines both public initiative and private inventiveness in an interactive way. While levels of vulnerability vary across the pop- 
ulation and across time, both public officials and local householders seek to solve the puzzle of drought. In some cases, public decisions articulate well with local adaptive strategies; in others, public policies may reinforce local vulnerabilities by increasing dependency relationships.

We intend to use a case study of Ceará State, Northeast Brazil, to document the articulation of public and private adaptations to climate variability. We argue in this paper that both public policies and private coping strategies are devised and revised within the cultural fabric of society, which in part influences their effectiveness. In a sense, the interplay of these public and private responses reflects the wider societal themes of clientelism and resistance that have characterized rural class relationships throughout Brazilian history (Johnson 1971). Cearálocated squarely in the semi-arid Northeast of Brazilprovides a unique context to examine this, since drought in this region has proven to be an intractable problem, despite major public efforts to reduce climate vulnerability. The case study draws upon current field research as well as historical evidence of past regional and local attempts to negotiate the drama of drought.

\section{SETTING: CEARÁ STATE IN NORTHEAST BRAZIL}

Brazil's Northeast is comprised of 9 states and encompasses $18 \%$ of the national territory as well as one-third of the country's population. Its semi-arid hinterland, the sertão, is known as the infamous 'drought polygon', which has recorded 5 centuries of periodic crisis. In a 'normal' rainfall year (about $750 \mathrm{~mm}$ for the Northeast), the winter rains arrive in December or January and diminish in May, with the heaviest precipitation occurring from February to April. In a drought year, the rains are not abundant enough to support an agricultural harvest, or the uneven distribution of rains does not meet timing requirements for crop moisture. Thus, even an annual average level of precipitation can incur a drought situation (referred to locally as a 'green drought').

Such climate variability has always been considered the major constraint to economic development as well as the principal cause of the numbing rural poverty that afflicts Northeast households. The rural economy of the semi-arid Northeast is based primarily on small-scale
Table 1. List of acronyms used in this paper

Banco do Nordeste do Brasil

(Northeast Development Bank of Brazil)

Companhia Hidroelétrica do São Francisco

(São Francisco Hydroelectric Company)

Companhia de Desenvolvimento do Vale do São Francisco

(São Francisco Valley Development Company)

Departamento Nacional de Obras Contra as Sêcas

(National Department for Works Against Drought)

El Niño/Southern Oscillation

Empresa de Assistência Técnica e Extensão Rural do Ceará (Rural Extension Office for the State of Ceará)

Fundação Cearense de Meteorologia e Recursos Hídricos (Ceará Foundation for Meteorology and Water Resources)

Inspectoria Federal de Obras Contra as Sêcas

(Federal Inspectorate for Works Against Drought)

National Oceanic and Atmospheric Administration

Secretaria de Desinvolvimento Rural (Secretary of Rural Development

Superintendência do Desenvolvimento do Nordeste (Northeast Development Agency)

rainfed agriculture and ranching. The majority of farm families are extremely land and resource poor and represent the most vulnerable segment of the rural population. Even under a normal scenario, these families experience difficulty in procuring basic necessities during part of the year; in a drought year, they face critical survival challenges, which traditionally have been answered by out-migration or major government emergency relief efforts. In fact, the social and economic impacts of drought reverberate through all sectors of society. The livestock sector, controlled primarily by large fazendeiros, also suffers from lack of pasture and water, and many animals either die or are sold off. Even in urban centers, water supplies are threatened, and local commerce virtually grinds to a halt.

The state of Ceará has 6 million people in an area of about $146000 \mathrm{~km}^{2}$. Approximately $40 \%$ of the economically active population is employed in agriculture and resides in rural areas. Every year, rural society anxiously awaits the onset of the rainy season, marking the beginning of the agricultural campaign, for the outcome of subsistence farming in Ceará is totally dependent on the quantity and distribution of these annual rains. ${ }^{1}$ In many ways, Ceará is the state that symbolizes for all Brazilians the horrors of drought in the Northeast, but at the same time, Ceará has led the effort to conquer it. Here, at the beginning of the 20th century, the federal government initiated its regional program to stockpile water in large reservoirs (açudes), and the

\footnotetext{
${ }^{1}$ In the conventional wisdom of the region, if the rains do not arrive by St. Joseph's Day (March 19), drought is assured
} 
large federal drought-fighting agency (DNOCS; see Table 1 for a list of acronyms) established its headquarters in Fortaleza, the state capital. It was in Ceará that cloud nucleation efforts were first introduced, and over the last decade, FUNCEME has become an internationally renowned meteorological organization that issues seasonal climate forecasts of the winter rains. The rainy season in Ceará, as in the rest of the Northeast, is influenced by the ENSO, whose signals are associated with below-average precipitation. FUNCEME has developed close relationships with the international scientific community to produce its forecasts using the ENSO and other data. Thus, with both an exceedingly high level of climate vulnerability and a major concentration of public effort, Ceará provides the setting for a unique study of the process of public and private adaptation.

\section{STUDY SITE AND POPULATION}

This paper is based on 2 yr of field research in Ceará (Fig. 1), funded by NOAA. In 1998, at the beginning of the expected rainy season, a formal survey of 484 households was carried out in 6 municípios, $^{2}$ each one representing different micro-climates within the state, from the arid Inhamuns region ( $500 \mathrm{~mm}$ of annual rainfall) to the northern coast $(1200 \mathrm{~mm})$. Within each município, the sample of households also reflected local spatial patterns in climate variability. In addition, the research team conducted systematic interviews with state and local policy makers whose responsibilities are related to climate, drought mitigation, water resource management, and agricultural development. In particular, the research focused on the dissemination of FUNCEME forecasts and the use of climate information by both farmers and the public sector to mitigate the impacts of drought.

While virtually all of Ceará is characterized as semiarid, there is in fact substantial variability from one region to another, as annual average rainfall data from the sampled municípios demonstrate in Table 2. Again, the interannual variation in average precipitation does not reflect the true vulnerability of the rural population, since rainfed agriculture requires a well-distributed pattern of rainfall over the cropping cycle, even for the fast-maturing varieties. Most farm households produce corn and beans as the basic subsistence staples with cotton, manioc, or cashew nuts as a cash crop, and most raise a limited number of small livestock (small ruminants, swine, or fowl). Three of the

\footnotetext{
${ }^{2} \mathrm{~A}$ município is about the size of a US county and is the local administrative political unit. The government of a município is a prefeitura, which is led by the local mayor, or prefeito
}

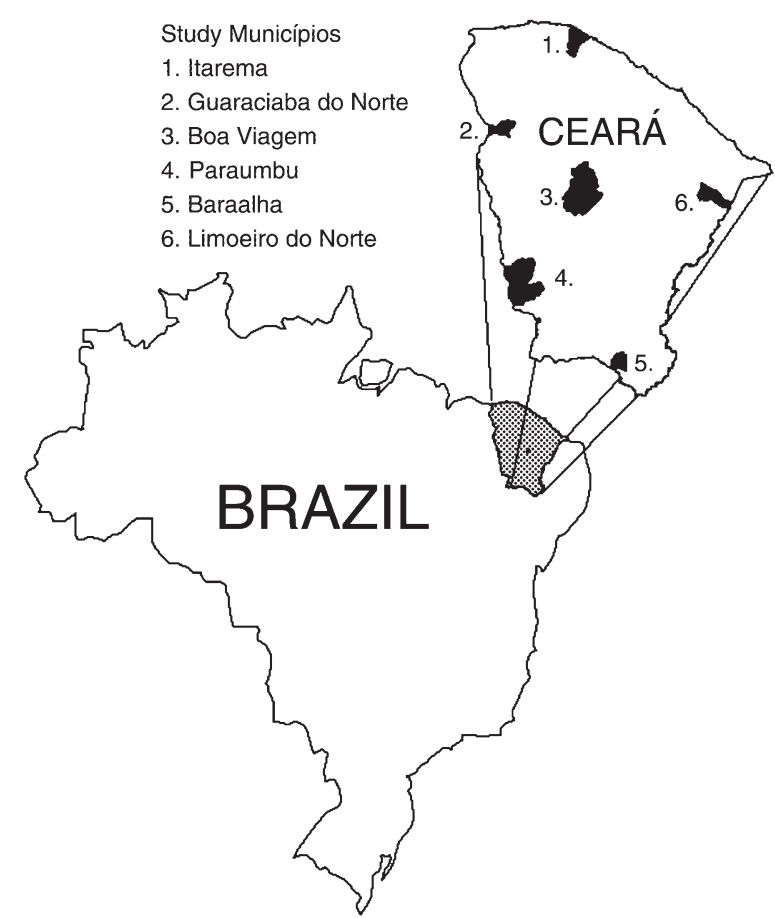

Fig. 1. Map of study area in Ceará, Northeast Brazil

municípios have significant levels of irrigated land; however, for the state as a whole, the percentage of irrigated area is negligible. The distribution of total owned land continues to be highly concentrated, but the manual technology employed in the rainfed farming limits the size of individual operational units. Most farms are operated by landless sharecroppers or independent smallholders and average approximately 5 to 8 ha within the rainfed municípios of the study.

Our sample of 484 households (2516 individuals) revealed an average household size of slightly more than 5 persons with an average age of 50 for the household head. ${ }^{3}$ While the rate of illiteracy has also dropped (to about $22 \%$ of the sample over $7 \mathrm{yr}$ of age), the total amount of formal schooling remains startlingly low in the rural areas. Only $11 \%$ of the sample over $15 \mathrm{yr}$ of age had finished the first $4 \mathrm{yr}$ of primary school. The result, of course, is a predominantly unskilled work force.

In order to understand the nature of climate vulnerability within this population, a classification of sampled household levels was constructed using quantitative survey information. For each household, the 1997 total physical production of basic subsistence crops (corn, beans, and rice) was recorded and then split into quar-

\footnotetext{
${ }^{3}$ Rural household size has been declining throughout the Northeast because of a lower number of births and widespread rural-urban migration
} 
Table 2. Annual precipitation for 6 municípios and the state, 1974-1998. na: information not available. Source: FUNCEME (unpubl data)

\begin{tabular}{|c|c|c|c|c|c|c|c|}
\hline Year & Limoeiro do Norte & Barbalha & Parambú & $\begin{array}{l}\text { Município } \\
\text { Boa Viagem }\end{array}$ & Itarema & Guaraciaba do Norte & Ceará \\
\hline 1974 & 679 & 1461 & na & 1068 & 2362 & 1598 & 1579 \\
\hline 1975 & 871 & 1235 & na & 992 & 1051 & 1605 & 1141 \\
\hline 1976 & 532 & 681 & na & 411 & 938 & 973 & 793 \\
\hline 1977 & 1060 & 930 & na & 833 & 1112 & 1373 & 1107 \\
\hline 1978 & 914 & 1168 & 266 & 548 & 1196 & 933 & 854 \\
\hline 1979 & 702 & 1390 & 475 & 460 & 441 & 1050 & 680 \\
\hline 1980 & 824 & 920 & 555 & 350 & 347 & 785 & 785 \\
\hline 1981 & 693 & 571 & 554 & 693 & 631 & 978 & 662 \\
\hline 1982 & 602 & 564 & 487 & 593 & 969 & 867 & 707 \\
\hline 1983 & 321 & 753 & 328 & 262 & 464 & 416 & 433 \\
\hline 1984 & 1289 & 1092 & 923 & 911 & 1296 & 1536 & 1119 \\
\hline 1985 & 1624 & 2148 & 2237 & 1371 & 2887 & 2602 & 1891 \\
\hline 1986 & 1310 & 1139 & 1114 & 973 & 1861 & 1961 & 1317 \\
\hline 1987 & 735 & 876 & 514 & 454 & 1041 & 1156 & 739 \\
\hline 1988 & 849 & 1321 & 814 & 869 & 1700 & 1428 & 1161 \\
\hline 1989 & 990 & 1567 & 1379 & 1122 & 968 & 1627 & 1266 \\
\hline 1990 & 425 & 791 & 494 & 550 & 689 & 1000 & 627 \\
\hline 1991 & 430 & 926 & 584 & 499 & 1281 & 1301 & 776 \\
\hline 1992 & 592 & 973 & 428 & 679 & 693 & 1008 & 694 \\
\hline 1993 & 286 & 744 & 490 & 184 & 616 & 484 & 420 \\
\hline 1994 & 684 & 1063 & 1016 & 761 & 1714 & 1780 & 1167 \\
\hline 1995 & 933 & 1059 & 767 & 751 & 1548 & 1462 & 1083 \\
\hline 1996 & 760 & 1529 & 624 & 668 & 1491 & 1422 & 1067 \\
\hline 1997 & 410 & 856 & 644 & 537 & 689 & 1259 & 709 \\
\hline 1998 & 313 & 759 & 344 & 395 & 923 & 714 & 493 \\
\hline Avg. & 721 & 1153 & 532 & 704 & 1140 & 1273 & 946 \\
\hline Min. & 286 & 564 & 266 & 184 & 441 & 416 & 420 \\
\hline Max. & 1624 & 2148 & 2237 & 1371 & 2887 & 2602 & 1891 \\
\hline
\end{tabular}

Table 3. Vulnerability category matrix. Category I: 213 Families, 44\%; Category II: 163 Families, $34 \%$; Category III: 108 Families, $22 \%$. US\$ $1 \approx \mathrm{R} \$ 1.8$

\begin{tabular}{|c|c|c|c|c|c|}
\hline \multirow{2}{*}{$\begin{array}{l}\text { Subsistence production } \\
\text { quartiles (per capita) }\end{array}$} & \multicolumn{5}{|c|}{ Income from agriculture and livestock quartiles (per capita) } \\
\hline & $\leq 100 \mathrm{R} \$$ & $100<\mathrm{R} \$ \leq 200$ & $200<\mathrm{R} \$<400$ & $>400 \mathrm{R} \$$ & Total \\
\hline$\leq 47 \mathrm{~kg}$ & 101 & 7 & 7 & 8 & 123 \\
\hline $47<\mathrm{kg} \leq 140$ & $\underline{95}$ & $\underline{10}$ & 7 & 8 & 120 \\
\hline $140<\mathrm{kg} \leq 405$ & $\overline{79}$ & 16 & 16 & 10 & 121 \\
\hline$>405 \mathrm{~kg}$ & 29 & 25 & 29 & 37 & 120 \\
\hline Total & 304 & 58 & 59 & 63 & 484 \\
\hline
\end{tabular}

tiles to provide a relative measure of food availability from household production. Similarly, the 1997 sales of all cash crops (cashew nuts, cotton, manioc, irrigated products, and coconuts) were added to the value of all animal assets (cattle, hogs, equines, sheep, goats, and fowl) and products, then split into quartiles to provide a relative measure of farm income. These 2 quartile distributions formed a matrix, and each cell was attributed to 1 of 3 vulnerability classes roughly referred to as the 'most' vulnerable, the 'least' vulnerable, and the middle range households (see Table 3 ). The most vul- nerable group was thus defined as having less than $\mathrm{R} \$ 200$ (US\$108) in per capita income from farm sales and livestock assets and as having produced in 1997 less than $140 \mathrm{~kg}$ per capita of subsistence staples. The least vulnerable group had over 400 reais in income or a combination of third quartile income and staple production. While somewhat arbitrary, this approach did provide a useful comparative framework for assessing climate vulnerability. In the final classification, $44 \%$ of the sample fell into the most vulnerable category and $22 \%$ into the least vulnerable one. 
In general, the most vulnerable families in our classification were those that have a larger household (by 1 member), significantly less education, significantly smaller farms, and fewer livestock. ${ }^{4}$ They also tend to be landless sharecroppers (59\%). It was further possible to compare the different coping strategies that households in different vulnerability classes employ to reduce their risks. Normally, agricultural activities cease in June, permitting households to seek other income-earning sources. The number of different income-earning strategies for the most vulnerable group is greater, which signifies a greater diversification by either income source or household member (i.e. husband and wife). Nonetheless, the total income per capita is still significantly lower than that of the other categories. We will further explore these implications in our discussion of private adaptations to drought below.

The years 1997 to 1999 were considered drought years from the perspective of the local population. In particular, the 1998 agricultural campaign occurred during an unusually strong ENSO signal in which FUNCEME had issued forecasts of 'below-average' precipitation. In fact, a severe drought did assail the region, prompting a major government response. In the following sections, we will relate the unfolding of this drama, but within the context of historical responses to drought.

\section{HISTORICAL RESPONSES TO DROUGHT}

In an analysis of historic responses to drought, it is necessary to distinguish between the long-term public strategies to prevent drought (or to 'minimize' drought impacts) with the immediate emergency relief of a population already in crisis. Throughout the 20th century, technology has provided the long-term strategy for eliminating the impacts of drought, as policy makers have searched within 'Science' for the means to eliminate this obstacle to development. Emergency relief, on the other hand, has typically relied upon a class-based power structure, weaving drought assistance into a patronage system that has plagued this society since its inception. Other public investments in rural society-not necessarily intended toward drought mitigation - have nonetheless generated positive externalities by expanding the private coping strategies of local communities and households.

While there is a written record of climatic crises in Northeast Brazil dating from Portuguese settlement,

\footnotetext{
${ }^{4}$ Of course, land size and animal ownership are not independent of the criteria for classification. Nonetheless, the magnitude of the differences is great, and therefore of interest
}

the calamitous drought of 1877, in which 500000 inhabitants perished, stimulated the first extensive and systematic mobilization of resources to reduce the suffering. The imperial government spent large sums of money to purchase food from other regions to distribute to the affected population of the Northeast. Furthermore, a National Commission of Inquiry was formed seek a more permanent solution to drought, and it produced a series of reports recommending the construction of canals, water resources, roads, ports, and the drilling of wells (Frota 1985, p. 144). During the 1904 to 1906 crisis, additional studies carried out in the Northeast generated similar recommendations and since then the public responsibility to address the problem of drought has been widely accepted.

The first technological solution was to store water. The first large public dam (Cedro Dam) was constructed in Quixadá, Ceará, between 1881 and 1906. In 1909, a drought-fighting bureaucracy was created: the IFOCS, which later became DNOCS (Frota 1985, p. 183). The major intent of DNOCS was to build the water supply infrastructure consistent with a technological approach (Magalhães 1993, p. 193). Between 1909 and 1983, 275 large dams were built with the capacity to accumulate 14 billion $\mathrm{m}^{3}$ of water. In Ceará, these reservoirs did not engender a major expansion in irrigated agriculture, and where large projects were introduced, they were beset by organizational and technical problems. Between 1945 and 1950, government institutions made an additional effort to strengthen agricultural production utilizing other technology-based strategies. New crops were introduced that were more resistant to drought, and farmers were advised to adapt to the ecological conditions of the semi-arid region by planting hardier varieties of crops (Magalhães \& Glantz 1992, p. 61).

In the postwar era, the problem of drought was addressed within a wider context of economic development and the overall commitment to modernization, primarily through industrialization and import substitution. The creation of CHESF provided the energy for industrial development in the Northeast, and between 1950 and 1970, 3 major organizations were established to initiate and manage the regional modernization effort: CODEVASF installed a major irrigation program along the São Francisco River; BNB was created to provide the financing, much of it under subsidized credit programs; and SUDENE provided the overall management apparatus to oversee the different development initiatives. As Frota (1985, p. 265-284) has pointed out, the modernization push did little to reduce the consequences of drought, primarily because the majority of the rural population did not have access to the programs.

In 1970, another major drought compelled the government to reassess drought mitigation policies in the 
region. On the one hand, a proposed solution was to reduce the population of the region by promoting outmigration to the sparsely settled Amazon. The Transamazonian highway system was constructed to channel the movement of people and goods, and in fact some families migrated out of the Northeast. On the other hand, policy makers sought to increase the resource base of small farmers. Various agrarian reform programs were designed to reduce the concentration of land resources and the overwhelming numbers of landless farmers. Under the military regimes of the decade, however, these efforts were resisted and never successfully implemented.

During the 1980s, investment in the rural economy was expanded with major World Bank financing of a series of integrated rural development projects. These intensive efforts specifically targeted smallholder agriculture and involved the institutional collaboration of SUDENE (as manager), BNB (as financing agent), and DNOCS (for technical support). The projects centered on sustainable socio-economic development as a method of reducing vulnerability to drought throughout the Northeast through access to water resources, credit, promotion of non-agricultural income sources, education, and health care (Magalhães 1993, p. 32-33).

During the 1990s, the World Bank continued to support programs intended to reduce the vulnerability of resource-scarce populations in Ceará. The inconsistent success of this effort is a matter of intense debate in policy circles and underlines the complexity of socioeconomic change in the region. On the one hand, the technology position continues to be defended on the basis that subsistence agriculture is simply non-viable in a semi-arid environment. The transformation of rainfed farming to an export-oriented irrigated agriculture is the long-term solution. A countering position is that further investment in building human and social capital and an expansion of productive assets (including effective land reform) will increase the feasibility of semi-arid agriculture. Unfortunately, neither of these strategies can solve the short-term reality of extremely vulnerable populations.

\section{ROLE OF CLIMATE INFORMATION IN DROUGHT MITIGATION}

FUNCEME was established in 1972, first as an organ of the state government dedicated to the scientific study of drought (and climate). High-profile visibility was achieved with its cloud-seeding program, which in local eyes was to trespass in the sphere of the Divine. The nucleation effort did not, of course, solve the problem of drought, but it did bring 'Science' center stage as a drought-mitigating strategy. In fact, in the eyes of many rural inhabitants, FUNCEME is still the organ that tries to 'make rain,' as mystical as that task must seem to a drought-ravaged population. In the late 1980s, FUNCEME, with a substantial injection of financial and human resources, initiated a seasonal forecasting service. The international scientific community has accompanied the evolution of FUNCEME closely, since it is a major case study of the application of scientific climate information for the benefit of society.

FUNCEME began to issue climate forecasts at the end of the 1980s and soon gained an unusually high level of prestige, reinforcing the expectation that Science could thwart drought and reverse the negative consequences of climate variability. This reputation achieved international recognition with an account of the 1992 drought that has been reiterated in both academic and government circles (Golnaraghi \& Kaul 1995, Glantz 1996, p. 80-81, Orlove \& Tosteson 1999). That year FUNCEME issued forecasts of drought and the then governor of Ceará traversed the state urging farmers to plant drought-resistant varieties of bean and corn seed-provided by the government. According to this account, while precipitation was significantly lower than the historical annual average, crop production dropped only slightly. The understanding - embraced by policy maker and scientist alike-was that FUNCEME and Science had saved the day. ${ }^{5}$

As the ordained representative of Science, FUNCEME was integrated into a wider government effort to mitigate drought. The timing of 2 major programs begun in 1992, one for seed distribution and the other for production credit, became tied to the forecast. The seed distribution program, called Hora de Plantar (Time for Planting), was managed by the SDR, which acquired quality seed for the upcoming campaign, but would only release the seed after FUNCEME had documented adequate soil moisture and had issued a favorable forecast to guarantee seed survival. The Bank of Brazil administered the credit program through local agencies that released funds only after the winter had been 'guaranteed' (assegurado) by FUNCEME. In such a system, the pronouncements of FUNCEME assumed an urgent public posture with

\footnotetext{
${ }^{5}$ We consider this account to be apocryphal based on our field research. First of all, not enough farmers participate in the seed distribution program to generate these differences; second, the extent of the governor's trip to the interior has been highly exaggerated; third, these results could as easily reflect the patterns of rainfall distribution throughout each year rather than annual totals; fourth, this 'amazing' result of climate information application was never repeated after 1992
} 
daily media coverage throughout the months preceding the onset of the rainy season. It is important to reflect on the central assumption of this drought prevention effort-that with accurate information and appropriate government action, the more disastrous impacts of drought could be avoided, if farmers cooperated.

Along with the public efforts to seek a long-term solution to drought, the Northeast also has a long history of reactive emergency response to crisis. The principal strategy since the beginning of the century has been that of public work fronts (frentes de trabalho), which continue to be a national symbol of suffering. Traditionally, the organization of these emergency relief programs was decidedly vertical and linear. Local officials informed the state government of critical levels of deprivation, which then was relayed through political channels to the federal government. Once crisis was declared, resources were then released at the federal level to move back down the structure to the state, to the município, to the flagelados (drought victims). In recent years, the National Civil Defense Agency has managed disaster control through regional coordination by SUDENE and state coordination by the State Civil Defense Agency. Federally allocated funds employ rural individuals on projects of public interest, predominantly the construction of roads, dams, schools, and so forth. Beneficiaries of the program receive a minimal salary, calculated as enough to guarantee the food security of rural households, albeit at basic survival levels.

These relief programs have had an infamous history, as the commonplace and cynical term, 'the drought industry' (indústria da sêca), connotes. In part, the top-down and weighted bureaucracy responsible for drought relief created organizational constraints that slowed the flow of resources and information to drought victims. More seriously, however, the large influx of money into drought-affected regions engendered widespread corruption and political manipulation of the suffering populace. Evidence abounds of work fronts clearing land or building dams on private fazendas (large landholdings), of phantom workers registered on the fronts, of non-existent tanker trucks contracted to deliver drinking water, of families not included in the program because of their local political affiliations. In effect, as these funds filtered into the local power hierarchy, they reinforced the clientelistic essence of rural society. Under these programs, the anguish of the masses fueled the profits of the more powerful, and at the end of a crisis, the relative positions of the advantaged had been strengthened. In recent times, the government has worked hard to reduce the effect of this clientelism on drought relief.

\section{PRIVATE ADAPTATIONS TO DROUGHT}

Drought in the Northeast has etched deep scars in the collective psyche of Northeast Brazil. Not only has drought been associated with human suffering, but also with diaspora. Historically, drought has driven people from their homes, scattered them throughout the Amazon ${ }^{6}$ and the industrialized south of the country. During the more severe crises of the 20th century-the 1958 drought for example-outmigration was the coping strategy of last resort for the most vulnerable segments of the population, since access to emergency programs was not always available. Often the very magnitude of the crisis overwhelmed the capacity of the government to respond, and the only avenue of escape led out of the region.

Current technologies reflect attempts to deal with the reality of a semi-arid environment. For example, farmers have selected seed for generations, favoring those plants that display drought-tolerant, early maturing characteristics. Different seed varieties (bearing the name of the person that first distributed it or the region of origin) are planted in different soil types as a strategy of diversification aimed at maximizing whatever moisture might arrive. The success of any given agricultural campaign is highly location-specific even within a município, following both the distribution of rainfall and the timing of planting. Farmers from Ceará are experienced risk managers who know the characteristics of their own land and seek to maximize their scarce resources. However, technologies specifically adapted to semi-arid conditions are no guarantee of a successful harvest when drought occurs.

The ability to cope with drought also strongly depends on stockpiled resources and access to nonagricultural income. The semi-arid environment and the socio-economic structure in Ceará produce seasonal hardships almost every year, and drought exacerbates this essentially chronic problem. In the face of such regular tribulation, households have developed a series of coping strategies to adapt to everyday life in a difficult region. A drought intensifies the dependence on these strategies, while stimulating other crisisspecific responses. In the discussion below, we have grouped these adaptive strategies into those that seek direct access to food, those aimed at income generation, and those focused on access to water for human and animal consumption. Our categories are admittedly arbitrary and not exclusive but useful for understanding the dynamics of adaptation to drought.

\footnotetext{
${ }^{6}$ It is safe to say that the majority of the non-Amerind population of the Amazon region has origins in the Northeast
} 


\subsection{Food-related strategies}

When production in a given year is seriously compromised, one initial response is a reduction in the amount and composition of household consumption. This food reduction strongly correlates with our vulnerability classification in 2 ways. First, the number of people who reported a reduction in total consumption during a drought year was $35 \%$ higher among the most vulnerable households than those within the least vulnerable category. Even more significant is the correlation with the changes in diet composition. While households in the least vulnerable category may reduce beef consumption, often substituting goat or chicken meat, the most vulnerable households reported eating only once a day with only occasional access to meat. Instead of beans and rice (the staple), the most vulnerable often subsist on sugar water with manioc flour. In the most severe crises, families have been driven to consume native plants, such as cacti and wild tubers.

During drought years, many families survive on both public and private food assistance, with the federal government providing the largest and most comprehensive food distribution program. Churches and other charity organizations also manage food relief activities but not as ongoing programs. Although access to this aid is literally a life-saver for some households, it does not eliminate hunger. The food baskets are small and in larger families may only last a week. Some local governments also provide school lunches-for some children in the sample, their only meal during the day.

The food strategy, mostly underreported (and its contribution to household livelihoods certainly underestimated), is the flow of food among and within families during periods of crisis. As a result of the extensive rural exodus, virtually any rural household has a relative in some urban area of the country. Even within a given rural community, because of access to resources or micro-climate variations, some families fare better than others in a specific year. Thus, in the context of crisis, social capital becomes a highly critical survival resource. Sons and daughters commonly send sacks of beans to parents; a brother in São Paulo sends some cash; a rich uncle in Fortaleza provides clothes. These flows of food, money, and other items, while difficult to measure, appear to be substantial.

Such social capital is also embedded in the social skein of the community. One woman, from a poor but somewhat more advantaged household, stated, 'as long as we have food, no one around here goes hungry.' Some landholders tend to provide sustenance to tenant sharecroppers during the crisis, reinforcing the clientelistic structure of society but also meeting an immediate and critical need. Local shopkeepers (com- erciantes), if they are able, also increase the amount of debt that they carry with local clients, even when acknowledging the improbability of repayment.

Finally, a significant political strategy that has emerged is that of looting of municipal commercial establishments and government warehouses. Food raids are signals to the government that the situation has reached crisis proportions, and they almost always take place at the end of a poor harvest season before relief programs have been initiated. In fact, looting is one of the formal indicators the State Civil Defense Agency utilizes to determine where to first direct the relief resources.

\subsection{Income-generating strategies}

A major food entitlement strategy is to generate the income to purchase it. In fact, the diversification of income constitutes a long-term adaptation to drought. Subsistence farmers have traditionally provided a labor pool in rural regions, due to the uncertainty and seasonality that characterize rainfed agriculture. Income-earning activities include day labor on farms and ranches, cutting and selling of firewood, and handicraft production, among others. The more vulnerable households have a larger number of income sources, but they generate a small amount of total revenue. The survey results also suggest that different municípios 'specialize' in certain types of income-generating activities. For example, in parts of Limoeiro do Norte and Itarema, the gathering of cashew nuts and processing of manioc provide employment for a large segment of the population. In another district of Limoeiro, rural households work in processing limestone. In Boa Viagem and Parambu, the major activity is wood gathering. While the allocation of family labor toward income-based employment is a regular feature of these subsistence livelihoods, the search for income opportunities becomes frantic during a drought. Some families engage in activities that they would not do during a normal year.

Thirty years ago, social security was made available to rural inhabitants who could demonstrate their regular dependence on agriculture as a principal livelihood. At $50 \mathrm{yr}$ of age, individuals - men and womenare considered eligible for the monthly pension of 1 minimum salary (approximately US\$76), and retirement has clearly become a major drought-mitigating strategy. In our survey, an average of $36 \%$ of the households had at least 1 retired member, while nearly $15 \%$ of the households had more than 1 retiree. Since it takes an agricultural day-worker a $6 \mathrm{~d}$ workweek to earn the minimum salary, the pension is an attractive alternative. Households receiving social security have 
a per capita income $73 \%$ higher than the younger families, and, as expected, there is no significant difference among vulnerability categories. In times of drought, the pension becomes a safety net, not only for the immediate household but also for other nearby relatives and neighbors, who turn to the retired for assistance.

As suggested above, migration plays an important role not only as a response to drought but also as an accepted adaptation to the semi-arid environment. Among the surveyed households, $31 \%$ received remittances, the vast majority in cash. In some cases, remittances are absolutely necessary to the maintenance of the household; in others this income simply increases the quality of life for family members. During normal years the majority of the migrants who assist with household expenses are young adults who seek wage labor opportunities in urban centers. In times of stress, there is an increase in the exodus of household heads, who remain away until the rains return. As with pensions, remittances tend to assist not only the immediate household but also a local network of needy families.

A final way people generate income in times of drought is through sale of livestock, tools, household goods, even cars and motorcycles. This type of response is obviously limited to those households that are least vulnerable and can dispose of such goods. The more vulnerable households tended to sell less valuable items that brought smaller income.

\subsection{Water-related strategies}

During a drought, water for consumption and household use literally dries up. Households normally obtain water from nearby reservoirs, a private or community well, or a home cistern. As drought conditions set in, water levels shrink, resulting in extremely high salt concentrations. As a consequence, families with nearby access to water during normal years may find themselves great distances from potable water in times of drought. During this time, much of the population becomes entirely dependent on the government to deliver water. In remote locations not served by the water trucks, people have limited options. They can either walk, sometimes many kilometers, to a reservoir or storage area that has water, or they can dig wells into the alluvial riverbeds, which is not always successful. Others, who have access to cash or trade items, hire people with some form of transportation to bring water back for the family. Water fees are not exorbitant but for cash-poor households, purchasing water on a daily basis is a serious strain. The increasing contamination of water sources during a drought also becomes a cause of gastro-intestinal infections, even cholera.
Livestock are particularly vulnerable to feed and water scarcity during a drought. Households have several strategies for livestock management during drought years. One is to sell off the herd before animals die. Not surprisingly, this option is much more common among the more vulnerable households which do not have the resources to maintain the cattle through hard times, even though glutted markets bring low prices. Many producers feed different cactus species, some native and others planted, even though the processing is an arduous task for certain types of cactus. Poorer households depend almost solely on this source of feed, while the wealthier ranchers can purchase hay and feed rations to survive the crisis. It is not uncommon for wealthier ranchers to transport their livestock to other states or areas less affected by the drought. Water for animals is also a major problem. While larger ranchers generally have access to water on their own land in the form of wells and dams, the more vulnerable ones are forced to utilize the water either from nearby wells or from reservoirs that may become too unsavory even for livestock consumption.

\section{PUBLIC RESPONSE TO THE 1998 ENSO DROUGHT}

The 1998 drought, following on the heels of the below-normal 1997 rainy season, was considered to be one of the worst in decades. The reservoirs that stockpile water throughout the state were already at low levels, especially the small and medium-sized ones that supply drinking water to rural towns and their outlying districts. FUNCEME had disseminated in 1997 a forecast of below-average rainfall, which was widely interpreted throughout the public (via the local media) as a message of drought. Early in the season, rains arrived in some areas of the state, but the Secretary of Rural Development and the banks did not release seeds and credit. In the public perception, FUNCEME had erred on the forecast, thus prohibiting seed distribution, and its scientific credibility came under intense criticism. ${ }^{7}$ The following year, despite a strong ENSO signal, the FUNCEME forecast, issued more demurely, did little to influence preparations.

The State Civil Defense Agency was aware of the likelihood of a drought in 1998 based on FUNCEME forecasts; however, proactive actions were not taken to mitigate the impending impacts. When adequate rainfall had not arrived by St. Joseph's Day (March 19) and drought loomed large in the national headlines, the

\footnotetext{
${ }^{7}$ It was common to hear during survey interviews that, 'if FUNCEME says there's going to be a drought, you'd better get ready to plant, because there's rain acomin'
} 
first outbreaks of social unrest occurred. Local farmers blockaded the major north-south interstate highway to intercept commodity trucks and several local communities reported warehouse looting. These actions stimulated local officials to seek help from the state and federal governments, and relief began to flow in May and June. A variety of targeting indicators were used to prioritize relief efforts, including information on actual precipitation, water supply availability, production, and local violence outbreaks.

Under the coordination of the state agency, a locallevel civil defense commission was developed in each município with representatives from 'all sectors' of society, including the prefeitura, rural labor unions, the Church, and farmer associations. These commissions registered families for relief assistance and identified the location and nature of public work front activities. In addition to the work front, which paid approximately R\$90 or US\$70 monthly, relief aid consisted of the monthly distribution of food baskets (cestas básicas). Local, state and federal funds provided tanker trucks to deliver drinking water to community cisterns or, in some cases, centralized individual cisterns to which surrounding neighbors had access. The state also purchased mobile desalinization machines to recuperate saline wells and reservoirs. The estimated cost in federal and state emergency aid for this drought was $\mathrm{R} \$ 450$ million (\$350 million in 1998 dollars). Throughout the state, 257000 people were employed on public work projects, and another 36000 participated in a paid literacy program. About 472000 food baskets were delivered monthly, and more than 400 water tankers were engaged in water delivery. ${ }^{8}$

The formation of the community-based civil defense commissions represents a stark contrast to the 'old' system that characterized the notorious drought industry. In comparison with past systems, where allocation decisions were made by a select few, a certain level of transparency and accountability was achieved due to the wide variety of representatives on the commissions. The blatant corruption of other days did not infect this relief effort, and where large landholders did benefit from infrastructure improvements on their properties, there were some conditions for public access. The public works projects generally focused on building water storage and access capacity, roads, or other infrastructure improvements. The innovative component of this relief program was the literacy project that paid beneficiaries to attend classes. Once the short course was completed, the graduates were moved into the public work groups and new participants were enrolled.

\footnotetext{
${ }^{8}$ These data are from interviews with State Civil Defense Commission officials
}

At the same time, however, socio-economic hierarchy of power did assert itself. The relief delivery process was initiated once the state acknowledged a 'state of emergency' for a given município, at which time a certain number of employment openings and food baskets were authorized. These relief measures were to be distributed according to need as determined by the commissions. As the crisis worsened, more and more assistance was extended to the município, then to households. At all levels, this distribution system was not entirely random, and political allegiances helped determine first which municípios and then which families were assisted more rapidly and more generously. Political enemies did not fare as well, despite the objectivity intended in the composition of the commissions.

With regard to private responses to this drought, the coping mechanisms cited above were actively employed. Most families interviewed 5 mo into the drought reported that the food basket was scarcely adequate to meet household needs, and they sought whatever income-earning opportunities possible. Many households sold their large livestock for lack of feed and water, but few were forced to sell their tools or household goods. It appears that substantial amounts of private assistance flowed through the social networks that tie rural people to friends and relatives in urban areas, particularly in the south, through the actions of emigrant solidarity groups organized in larger cities, through private donations from individuals sensitized to the horrors of drought by the national media coverage, and through religious organizations. As a result, there were no significant increases in outmigration or in rates of malnutrition. In contrast to the tragic consequences of past crises with significant rates of mortality, the drought of 1998 did not incur the loss of human life. Rather, the rural population endured at the margin of survival, with much suffering, using the meager protection at hand to outlast the ravages of this particular crisis.

\section{CONCLUSION: POLICY IMPLICATIONS FOR ADAPTATION TO DROUGHT}

This case study of Ceará provides important insights into the complexity of drought response. The record of public attempts to mitigate the impacts of climate variability suggests that the investment in technological solutions has yielded little success. Socio-economic and cultural constraints, such as illiteracy, clientilism, and class, continue to weaken the potential of science and technology to buffer against drought. The storage of large amounts of water in reservoirs throughout the state has not reduced the vulnerability of the majority 
of farmers, and existing irrigation projects either have faltered due to poor management or have been dominated by wealthy investors and multi-national agricultural corporations.

The role of FUNCEME in mitigating droughts has also highlighted the limits of science. Its institutional credibility was damaged by political turbulence, which served to divert attention from the true value of its climate prediction system. The 1992 proclamation of success implied that farmers could use forecast information to (miraculously) produce-yea, even in the teeth of a drought-if only they heeded government directions. This infusion of politics into the realm of climate forecasting, guaranteeing harvests in dry years, created false expectations among the public, which soon turned to resentment when the inevitable occurred-a perceived forecast in error.

In 1998 FUNCEME, influenced by the results of this research, changed its policy directions. It no longer announces the annual forecasts in large media settings and has explicitly reformulated its identity as that of an information-gathering organization, rather than a policy-making one that tells farmers when to plant. Again, in response to project recommendations, FUNCEME has begun to develop strategies that better package forecasts and make them more user-friendly. This was initiated through training courses for extension agents at EMATERCE at the end of 1998. FUNCEME is currently evaluating the courses and is actively seeking ways in which it can more effectively communicate with farmers who, though they do not credit current forecasts, express interest in creating closer ties with FUNCEME. Some of the methods being explored are increased contact with farmer associations and utilizing rural radio networks to broadcast taped forecasts, thereby avoiding past miscommunication problems.

A wider policy implication of this research is the need to plan for drought, which is where public and private response can form the most effective partnerships. Once it is understood and accepted that drought is a normal feature of the semi-arid environment of the Northeast, then proactive planning becomes possible. The critical components of such planning are shortterm policies for minimizing the impacts of the next drought and longer-term policies to reduce vulnerability to all droughts. It has been our recommendation that such planning originates at the local level of government, where municípios are in a better position to fit planning priorities to local realities. In fact, statesponsored pilot projects to develop município-level plans for living in and with the semi-arid are currently underway in 5 municípios. The plans are being developed by the municípios themselves and incorporate both long- and short-term aspects. As a short-term response, when a seasonal climate forecast suggests the likelihood of a crisis, local governments will have a blueprint to mobilize a series of previously defined mitigation strategies. Likewise, locally developed, longterm plans are designed to enhance the resilience of the population. Although, in rural society, drought still reinforces the clientelistic social structure and reentrenches the position of the current power-holders, by engaging communities in the development of these plans, these types of relationships can be reduced.

This research demonstrates that the reduction in climate vulnerability is an integral component of an overall development process. The most vulnerable households fundamentally need to expand their economic and human capital resource base. Current government programs to support family agriculture are making an effort to increase the assets of local communities through farmer associations, land reform, and the integration of rural producers into national markets. Furthermore, the ambitious strategy of the government, about to be implemented, is to transfer water across watersheds, so that regions of the state with cultivable soil will have water.

This case study further demonstrates that certain public interventions, perhaps unintendedly, have actually augmented household adaptive strategies. Most saliently, the rural retirement system has injected much-needed cash into an economy where adequate income-earning alternatives are traditionally scarce. There is anecdotal evidence from our survey that the stability of this income source has reduced the rural exodus and perhaps even attracted young, unmarried household members back from the cities. For households with pensions, drought is less daunting a spectre, even if a crisis puts added strain on household cash. A second form of government policy that has inadvertently expanded private adaptations is public investment in rural infrastructure, primarily roads, rural electrification, and telecommunications. Every município (although not every outlying district) now has yearround road access, interstate bus service, and electricity. In addition, the first gift that emigrant children send back to rural parents is the parabolic antenna and a television, so that virtually all households have access to their own television or to that of a neighbor. The expanded infrastructure has facilitated the movement between rural areas and cities, has brought new flows of information into rural households, and, as importantly, has broadcast the plight of drought victims to the rest of the country.

In this paper, we have recounted a case study of drought, placing it within a historical context that viewed drought more as a climatic rather than a socioeconomic phenomenon. As a result, public and private efforts to mitigate impacts do not always intersect. Public policy, especially when informed by unques- 
tioning faith in science and technology, cannot resolve the problem of drought (or any other climate crisis) without a concomitant response from the private side of rural households and communities. In effect, public policies enjoy the best outcomes when they expand the adaptive capacity of the population. Since such private adaptations are embedded in complex, power-differentiated structures, the true challenge lies in the organization of response within such socio-economic constraints.

The intersection of public and private responses is best accomplished not only in terms of immediate responses to drought, but through 2 interrelated strategies. The first is to enhance the ability of families to become less vulnerable. This is done not only through implementation of technology, but also through programs that strengthen the socio-economic well-being of families. The second strategy is to treat drought as a matter of fact in a semi-arid region-the normal state of affairs, rather than the extreme. Such an approach would presume a proactive stance to drought mitigation with a program of on-going actions to eliminate the consequences of crisis on a vulnerable population.

\section{LITERATURE CITED}

Baro MA (1997) Evaluation de la Securité des Conditions de Vie dans le Département de Maradi au Niger. (Monitoring of livelihood systems in the Department of Maradi in Niger). Report presented to USAID

Corbett J (1988) Famine and household coping strategies. World Develop 16(9):1099-1112

Davies S (1996) Adaptable livelihoods: coping with food insecurity in the Malian Sahel. MacMillan Press Ltd, London de Carvalho O (1994) O impacto social da seca no Nordeste.
Paper presented to the Conferência Nacional e Seminário Latino-Americano da Desertificação in Fortaleza, Ceará

Finan TJ (1994) Adaptive responses to climatic change in the Kanem Region of Chad: the applied anthropology of food security. Paper presented to the Annual Meetings of the Southwestern Anthropological Association, Las Vegas, NV, April

Frota G Pinto da, de Aragão LS (1985) Documentação Oral e a Temática da Seca. Centro Gráfico, Senado Federal, Brasília

Glantz MH (1996) Currents of change: El Niño's impact on climate and society. Cambridge University Press, Cambridge

Golnaraghi M, Kaul R (1994) The science of policymaking: responding to El Niño. Environment 37(4):16-44

Johnson A (1971) Sharecroppers of the Sertão: economics and dependence on a Brazilian plantation. Stanford University Press, Palo Alto

Liverman DM (1990) Drought impacts in Mexico: climate, agriculture, technology, and land tenure in Sonora and Puebla. Ann Assoc Am Geogr 80(1):49-72

Magalhães AR (1993) Drought and policy responses in the Brazilian Northeast. In: Wilhite DA (ed) Drought assessment, management, and planning: theory and case studies. Kluwer Academic Publishers, Boston, p 181-198

Magalhães AR, Glantz MH (eds) (1992) Socioeconomic impacts of climate variations and policy responses in Brazil. Esquel Brazil Foundation, Brasilia

Orlove BS, Tosteson JL (1999) The application of seasonal to interannual climate forecasts based on El Niño-Southern Oscillation (ENSO) events: lessons from Australia, Brazil, Ethiopia, Peru and Zimbabwe. Berkeley Workshop Environ Polit Working Pap 99(3), Institute of International Studies, University of California, Berkeley

Ribot JC, Magalhães AR, Panagides SS (eds) (1996) Climate variability, climate change, and social vulnerability in the semi-arid tropics. Cambridge University Press, Cambridge

Watts M (1993) Silent violence: food, famine, and peasantry in Northern Nigeria. University of California Press, Berkeley

Wilhite DA, Easterling WE (eds) (1987) Planning for drought: toward a reduction of societal vulnerability. Westview Press, Boulder

Proofs received from author(s): August 16, 2001 